IJIET, e-ISSN 2548-8430, p-ISSN 2548-8422, Vol. 1, No. 1, January 2017

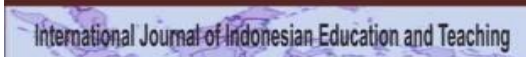

IJIET

International Journal of Indonesian Education and Teaching http://e-journal.usd.ac.id/index.php/IJIET

Sanata Dharma University, Yogyakarta, Indonesia

\title{
PRIMARY SCHOOL PRE-SERVICE TEACHERS' PERSPECTIVES ON PRIMARY YEARS PROGRAM AND ITS IMPLEMENTATION
}

\author{
Theresia Yunia Setyawan \\ Primary School Teacher Education Program \\ Faculty of Teacher Training and Education \\ Sanata Dharma University \\ theresiayunia@usd.ac.id \\ https://doi.org/10.24071/ijiet.v1i1.325
}

\begin{abstract}
As one of the most widely used international primary curricula in the world, the Primary Years Program (PYP) introduced by the International Baccalaureate Organization (IBO) has significantly increased its number of world schools in the Asia Pacific region including Indonesia. With the increased number of IB World Schools in the country, there comes a need to prepare for teachers qualified for teaching using the PYP as their framework. Indonesian higher educational institutions are therefore required to not only prepare teachers qualified in their teaching profession but also those having an open mind towards international education in general. It is important, then, to have insights on what these pre-service teachers think about international primary education, especially about the PYP and its implementation in primary schools in Indonesia. These perspectives will make useful raw data on the characteristics of Indonesian primary pre-service teachers and their readiness to take their professional career in any international primary schools including the IB world schools.
\end{abstract}

Keywords: primary school pre-service teachers, Primary Years Program (PYP)

\section{Introduction}

In a globalized world where there is almost no barrier of communication between countries, there is a need for individuals to connect to each other and be part of the world. Responding to this situation, educational institutions are taking more and more responsibilities to prepare these individuals to take part in this global citizenship. They are liable to endue young generations attending schools with international-mindedness that will aid them to become more conscious of their roles and contributions as part of the globalized world and, thereby, as members of an international community.

The International Baccalaureate Organization (IBO) founded in 1968 is one non-profit educational organization concerned with this global citizenship issue. Having the mission to develop inquiring, knowledgeable and caring young people who help to create a better and more peaceful world through intercultural understanding and respect (International Baccalaureate Organization, 2007:4), it offers every level of education a program aiming to help schools across the world 
develop active, compassionate students and lifelong learners who understand that other people, with their differences, can also be right. In general, it aspires to encourage well-rounded students with characters ...

... who respond to challenges with optimism and an open mind, who are confident in their own identities, make ethical decisions, join with others in celebrating our common humanity and are prepared to apply what they learn in real-world, complex and unpredictable situations. (International Baccalaureate Organization, 2012:2)

Inspired by this mission, many schools around the world have started to adopt at least one of the International Baccalaureate (IB) programs and have now called themselves IB World Schools. In the Asia Pacific region alone, its specialized program offered at the elementary level - the Primary Years Program (PYP) has undergone significant growth during the past ten years. By the end of 2013 the program has been adopted by more than 800 schools in the region compared to only 175 schools in 2004 (check http://ibo.org/facts/schoolstats/growth.cfm for more accurate current data). The substantial growth can also be witnessed in Indonesia since its first school authorization in 1978. Among 40 IB World Schools offering one or more of the three IB programs in the country, there have been 28 schools offering the PYP. This number will likely increase in the near future considering the fact that there are still a number of candidate schools waiting to be authorized as IB World Schools.

Considering its progressive mission as well as taking into account its significant growth in its number of schools around the world and specifically in Indonesia, the Primary Teachers Education Program of Sanata Dharma University Yogyakarta has the initiative to introduce the program to its junior or third-year students through an elective course labelled as Primary Years Program (PYP). It is expected that, by learning about the PYP, these primary pre-service teacherscan also learn and have insight about a new curriculum other than the one issued by the Indonesian government. Further, by learning about this international curriculum, the students preparing themselves to be primary in-service teachers can broaden their understanding about how the educational world works and, thereby, can make better decisions concerning their teaching profession later inthe future.

Along with the fast number of growth of primary schools adopting the PYP framework, it becomes essential to prepare teachers who are not only capable of teaching within the framework but also have an open mind to adapt themselves to the mission and vision of the IB PYP. Their perspectives on how the framework should be adopted and implemented by local schools becomes vital as they are likely to gain their teaching profession in their local context. Further, because these pre-service teachers will likely to be the spearheads in any educational institutions they will belong to, their views on the curriculum adopted and implemented becomes even more important as these views will affect the decisions and choices they make during the teaching and learning processes. 


\section{The Primary Years Program (PYP)}

The Primary Years Program (PYP) is one of the four instructional programs offered by the International Baccalaureate Organization (IBO). It was pioneered by an idea for a program for students aged 3-12 discussed at the ECIS (European Council of International Schools) Conference in Rome in 1990. Kevin Bartlett from Vienna International School led a steering committeestarting the International Schools' Curriculum Project (ISCP) ages 3-12 in 1992 before the project was finally introduced by the International Baccalaureate Organization as the Primary Years Program in 1997. Along with its other three programs, i.e. Middle Years Program (MYP), Diploma Program (DP), and International Baccalaureate Career-related Certificate (IBCC), the PYP aims to develop knowledgeable and caring young generation who always inquires in order to help create a better and more peaceful world through respects and cross cultural understanding. It aims to develop learners who strives to be inquirers, knowledgeable, thinkers, communicators, principled, open-minded, caring, risk- takers, balanced, and reflective.

The PYP framework consists of three curricula, i.e. the written curriculum, the taught curriculum, and the assessed curriculum. The written curriculum is designed to answer the question "What do we want to learn?" as it serves as the framework identification of what is worth knowing. The taught curriculum is aimed at providing answers to the question "How best will we learn?" for it consists of the theory and application of good classroom practice. The assessed curriculum responses to the question "How will we know what we have learned?" by providing the theory and application of effective assessment. The relationship of these three interrelated curricula is depicted in the picture that follows.

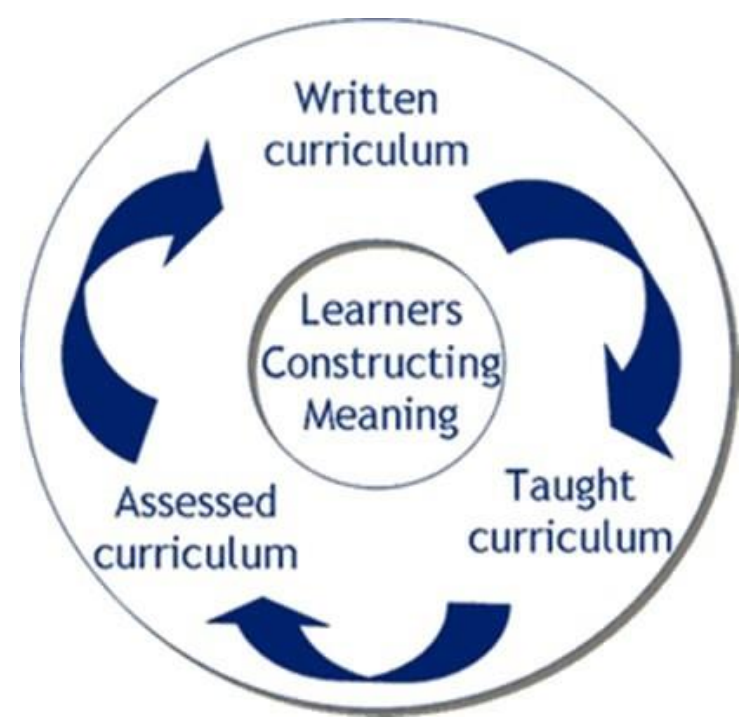

Figure 1. PYP Definition of Curriculum (International Baccalaureate Organization, 2007:7)

The picture shows that the PYP curriculum is a composite curriculum where each component is equally valued. The double-headed arrows indicate that 
developing, implementing, and assessing the curriculum is an iterative process where each component informs the other two. In all, this process is aimed at facilitating the learning process in which learners construct their own knowledge and understanding.

The written curriculum of PYP comprises five essential elements that students need to learn and acquire during their study at an IB school. Those elements are concepts, knowledge, skills, attitudes, and action. Concepts are solid ideas not only relevant to but also beyond subject matters. This means that students need to reexamine the ideas over and over so that they can construct deeper understanding of the subject matters in hand.Knowledge is all the relevant and significant information of which we want the students to know and inquire by taking into account their previous experiences and understanding.Skills are disciplinary as well as transdiciplinary abilities that students need to possess and demonstrate in order to be able to succeed in a challenging and continuallychanging world. Attitudes are dispositions which are expressions of fundamental values, beliefs, and feelings about learning, environment, and people. Action is demonstration of deeper learning in responsible behaviour through responsible action. It is a practical manifestation of the other four essentialelements.

The concepts element consist of eight notions significant for designing a transdisciplinary curriculum. The first four notions are form, function, causation, and change which signify the questions, "What it is like?", "How does it work?", "Why is it like it is?", and "How is it changing?" respectively. The other four notions are connection, perspective, responsibility, and reflection. Each of them correspondingly address the conceptual questions "How is it connected to other things?", "What are the points of view?", "What is our responsibility?", and "How do we know?".

The knowledge element elaborates the importance of traditional subject areas, i.e. language; mathematics; social studies; science; personal, social and physical education; and the arts. These areas are taught through a transdisciplinarymodel where there is no separation among them. This transdisciplinary model is achieved through six transdisciplinary themes considered essential in the context of a program of an international education. These themes are Who We are, Where We are in Place and Time, How We Express Ourselves, How the World Works, How We Organize Ourselves, and Sharing the Planet. The International Baccalaureate Organization selected these themes because they ...

- have global significance - for all students in all cultures

- offer students the opportunity to explore the commonalities of human experience

- are supported by knowledge, concepts and skills from the traditional subject areas but utilize them in ways that transcend the confines of these subjects, thereby contributing to a transdisciplinary model of teaching and learning

- will be revisited throughout the students' years of schooling, so that the end result is immersion in broad-ranging, in-depth, articulated curriculum content 
- contribute to the common ground that unifies the curriculums in all PYP schools

(International Baccalaureate Organization, 2007:11)

Along with the development of the conceptual knowledge, PYP students also need to develop their transdisciplinary skills such as thinking skills, social skills, communication skills, self-management skills, and research skills. Each of these five essential skills cover a number of specific skills and all of them are valuable, not only in the process of designing the lessons, but also for any teaching and learning activities that goes on within the classroom as well as in lifeoutside the school (International Baccalaureate Organization, 2007:21).

The PYP framework recognizes that knowledge, concepts, and skills alone do not necessarily create an internationally-minded person. PYP learners need to develop personal attitudes towards other people, towards the environment and towards their learning itself. These attitudes should contribute to the well-being of the learners themselves as well as of the group of which they belong to. The attitudes that the PYP strives to nurture in its every learners are appreciation, commitment, confidence, cooperation, creativity, curiosity, empathy, enthusiasm, independence, integrity, respect, and tolerance.

The last element in the PYP framework is action. Responsible actions are believed to be the results of the learning processes initiated by students. The framework provides every student with the right and opportunity to be involved in the actions either individually or in groups. The action element can encompass services to self, to fellow students, to staff, or to community. Through this service, it is expected that students can develop themselves both individually and socially, develop their cooperative, problem-solving, conflict-resolution, as well as creative and critical thinking skills. The actions are ways of which students show their commitment to achieve the PYP learner profile and of which teachers always strive to encompass in every learning in every PYP class. Moreover, specific actions that students choose can be considered as the most significant summative assessment indicating the success of the implementation of the PYP framework. The PYP written curriculum and its essential elements can be summarized in the following picture.

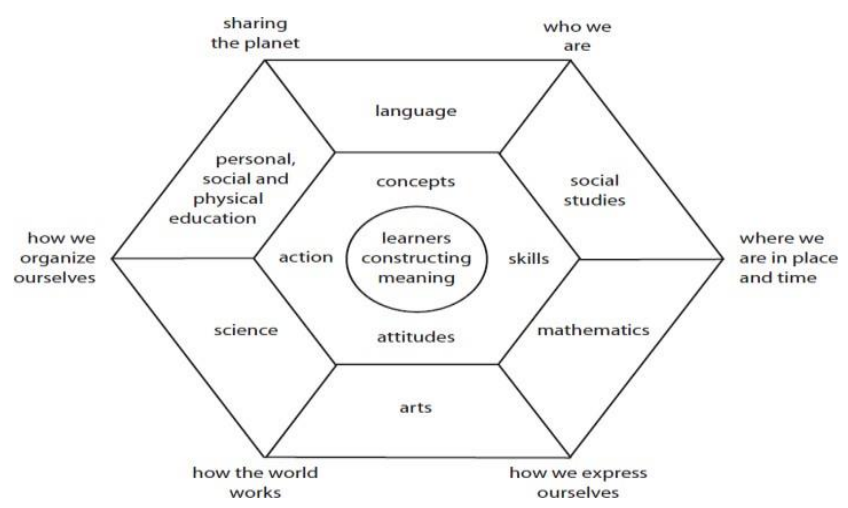

Figure 2. The Synthesis of the Essential Elements of the PYP (International Baccalaureate Organization, 2007:58) 
The taught curriculum of PYP is basically its written curriculum in action. It synthesize five essential elements of learning in three main ways, i.e. through the learner profile, the exploration of conceptually based central ideas, and the collaborative planning process. The PYP believes that every student is a unique individual that actively involves in and takes responsibility for their own learning. Hence, students will become more enduringly skillful when the learning is authentic and in context. Parallel to this belief, the PYP intends to support students' efforts to construct meaning from the world around them by drawing on their prior knowledge, by providing provocation through new experiences, and by providing time and opportunity for reflection and consolidation (International Baccalaureate Organization, 2007:9). In short, PYP means to assist students to move from their current level of understanding to a new and deeper level of understanding through the processes initiated by the teacher or the students themselves. Simply put, it aims to facilitate students to use their background knowledge to approach new situations and to ask questions to find out more (Babin \& Binns, 2011). In its broadest sense, then, this is known as the inquiry approach and has become the spirit of the PYP since its inception. The inquiry cycle in the PYP is depicted in the figure below.

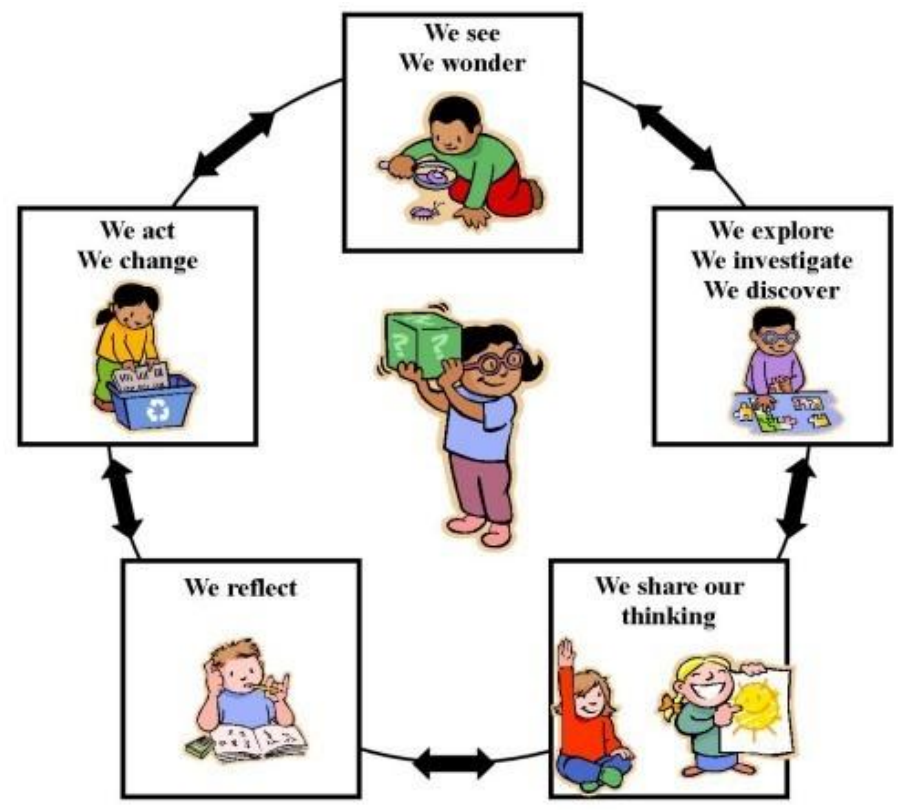

Figure 3. The Inquiry Cycle in the PYP (graphic fromhttp://www.summit.k12.co.us/Page/1714)

The cycle shows that students are triggered by what they see and what are interesting around them. As they observe this phenomenon or problem, they are guided to explore and investigate in order to discover answers to the observed phenomenon or problem. In the next phase of inquiry, teacher will need to encourage the students to share their thinking and findings and, later, reflecting on their as well as others' discoveries. This reflecting session is important because it 
will empower the students to choose and act a certain action that will make a change, as small as it can be, to the world around them.

The assessed curriculum, as its name indicates, proposes to provide feedback on the students' learning process by collecting and analyzing information about students' performance. The PYP approach to assessment recognizes the importance of assessing the students' process of inquiry as well as the product(s) of inquiry and aims to integrate and provide support to both entities. As PYP focuses on students' learning, its assessment will consider obviously consider the nature of students' inquiry, students' awareness, and mastery of skills, comprehensive knowledge base, independence and their ability to work collaboratively. PYP teachers, as a consequence, are encouraged to use various types of assessment strategies (e.g. observations, performance assessments, process-focussed assessments, selected responses, open ended tasks, etc.) as well as assessment tools (e.g. rubrics, exemplars, checklists, anecdotal records, etc.).

Overall, and just like any other IB programs, the PYP is laden with three basic tenets underlying the IB philosophy. These beliefs, as Erickson (2008)elaborates, are holistic learning, intercultural awareness, and communication. By holistic learning, the IB PYP means to encourage students to consciously learn how to learn and use their metacognitive skills and prior knowledge to construct their own knowledge and, thereby, create deeper understanding. Through intercultural awareness, the IB PYP is committed to help students to develop attitudes, knowledge, and skills that reflect their international-mindedness and be ready to be part of global citizenship by knowing other cultures as well as their own, focusing on global issues, becoming informed and sensitive to the experiences of others, and providing service to local, national, or international communities. By means of communication, the IB PYP seeks to assist students to develop a strong command of verbal and nonverbal communication by encouraging their proficiency in one or more additional languages, promoting understanding and appreciation of the arts as well as information technologies as other modes of communication.

\section{The Implementation of Primary Years Program in Indonesia}

As mentioned previously, among all the IB world schools in Indonesia, the PYP framework is adopted by 28 schools of which most of them are labelled as international schools. These schools spread across the three biggest islands in Indonesia (i.e. Sumatra, Java, Kalimantan) and West Nusa Tenggara. Labelled as international schools, however, the schools adopting the PYP framework still strive to adopt the customs, cultures as well as local values of the societies where they are located. This is important because, in order to develop an individual with an international-mindedness, it is necessary to develop their awareness of the local values of the community to which they belong first.

In accordance with the framework, the learning and teaching processes in the schools are organized around six transdiciplinary themes with each theme encompasses one or more ideas of the five essential elements of the PYP framework. Working cooperatively, class teachers are responsible for developing 
six units of inquiry - with each unit covering one transdisciplinary theme specifically designed for their classes. Put together, all the units of inquiry that the teachers design for their classes will form the schools' program of inquiry.

\section{Research Method}

This research was a one-shot pre-structured qualitative survey aiming at studying the diversity of perspectives on the PYP framework and its implementation among primary pre-service teachers of Primary Teacher Training Program of Sanata Dharma University. Unlike statistical surveys, this qualitative survey aimed to determine the variation of the primary pre-service teachers' perspectives on the topic in question and does not mean to establish frequencies, means or other statistical parameters (Jansen, 2010). It was categorized as a prestructured qualitative survey because, as further put by Jansen (2010), the categories of questions were defined beforehand and the identification of the answers to the questions was completed through a structured questioning protocol using a questionnaire. Further, this study was claimed to be one-shot survey for it only involved one empirical cycle of generating research question, data collection process, data analysis, and report writing. The steps of which it was conducted can be illustrated as follows.

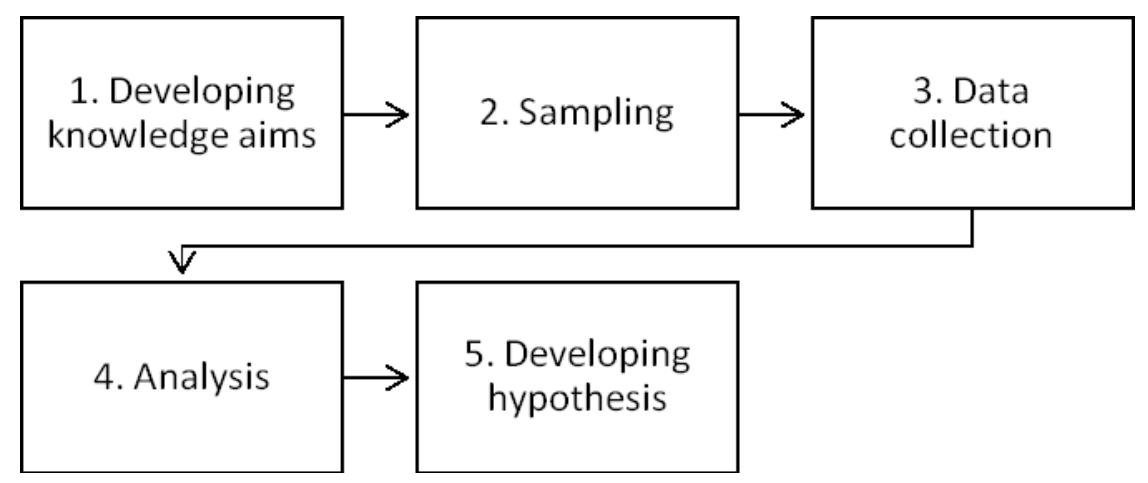

Figure 4. The Steps of Qualitative Survey (adapted from Jansen, 2010)

The figure shows that there are five main steps of which the study was proceeded. The first step of developing knowledge aims covers things like determining the topic (the PYP and its implementation) and its aspects (primary pre-service teachers' perspectives) under study. The sampling step encompasses the method of sample selection as well as the criterion of the size of the population. This study took 82 sixth semester students taking the PYP course as their elective subject as its subjects under study. Further, for the purpose of practicality, these students were chosen among all the six classes taking the coursenon-randomly. They were the students belong to the classes where the researcher taught the PYP course.

The third step of the qualitative survey procedure is the data gathering step. The step initiated with the construction of a questionnaire as the major instrument of this research. The questionnaire in question included both closed and open questions aiming at elaborating the perspectives of the research subjects on the 
topic being investigated. It was constructed in the students' native language so that there was no misunderstanding about the instruction and the interpretation of the questions. Further, to ensure its response rate, the questionnaire was distributed as one of their compulsory assignments during the course.

Analysing the data gathered through the questionnaire is the next step in this research. This phase included coding the data and classifying them into categories. The result of the coding and categorization of data was then described and synthesized to form patterns and concepts. It was also the phase where the relationships between concepts and patterns were explained thoroughly based on the PYP literatures and practices. Once the explanation was complete, a hypothesis which was based on the data analysis could be formed as the last step of the research. The hypothesis then served as the conclusion of the research as well.

The instrument of this research was a questionnaire containing seven questions related to PYP and the students' perceptions on the curriculum as well as its possibility of implementation in their own local educational context. Before being distributed to the students, the questionnaire had been validated by two other lectures teaching the PYP course. The researcher had also tested its readability to two students chosen randomly from the other four classes not being used as the sample of the study.

As the aim of this research was to identify the variation of the primary preservice teachers' perspectives on the topic in question, answers from the filled-out questionnaire gathered from the 82 studentswere categorized and analyzed based on their similarities and differences. The students' responds were grouped based on the seven questions in the questionnaire and then compared to see their resemblances as well as variances. As the patterns of resemblances and variances appear among their various responses, analysis on the patterns were made to answer the question proposed at the beginning of the study.

\section{Results and Discussion}

In response to the first question What does the PYP look like?, it could be summed up that the respondents viewed the PYP as a concept-based curriculum designed for students aged three to twelve years old. The curriculum encompassed six subjects, i.e. Language, Social Studies, Mathematics, Arts, Science, and PSPE (Physical, Social, and Personal Education), which are covered in six transdisciplinary themes, i.e. Who We are, Where We are in Place and Time, How We Express Ourselves, How the World Works, How We Organize Ourselves, and Sharing the Planet.

The respondents also shared beliefs that the PYP would help learners to have positive attitudes toward learning and, hence, would help them to be lifelong learners through its emphasis on inquiry learning. It was also agreed that ithelpedfacilitate learners to be global thinkers through the use of more than one language in its teaching and learning processes as well as through the exhibition project that the learners needed to organize at the end of their learning period. The followings are the excerpts taken from the respondents' responses showing the elaborated points. 
... dalam PYP sudah disepakati untuk menerapkan kurikulum yang dimotori oleh konsep sebagai sarana untuk mendukung inkuiri. Ada delapan konsep yang ditetapkan sebagai konsep yang sangat penting yaitu bentuk, fungsi, sebab akibat, perubahan, hubungan/keterkaitan, sudut pandang, tanggung jawab, dan refleksi/perenungan. Konsep tersebut diuraikan dalam bentuk pertanyaan-pertanyaan inti yang nantinya akan digunakan oleh guru dan siswa secara fleksibel ketika merancang unit yang berdasarkan inkuiri. (S166)

Di tahun akhir program PYP, siswa akan membuat proyek sederhana, disebut exhibition, secara berkelompok. Tujuannya adalah untuk melatih siswa dalam menerapkan pengetahuan yang mereka dapat di kelas ke dalam proyek-proyek kreatif. (S233)

Setiap siswa diharuskan mempelajari lebih dari satu bahasa yang terdiri dari satu bahasa utama dan minimal satu bahasa tambahan. Tujuannya adalah agar siswa mampu berkomunikasi di dalam dunia pergaulan internasional serta bisa menghargai keragaman budaya di dunia. (S258)

All in all, as indicated by the following quotation, the respondents agreed that the PYP aimed to develop learners who, as stated in its learner profile, were knowledgeable, caring, reflective, inquirers, open-minded, communicators, risktakers, principled, balanced, and thinkers.

Dalam kurikulum PYP ini, siswa diupayakan untuk memiliki rasaingin tahu (inquirers), berpengetahuan luas (knowledgeable), berpikir kritis (thinkers), komunikator (communicators), berprinsip (principled), berpikiran terbuka (open-minded), memiliki kepedulian (caring), berani menanggung resiko (risk-takers), seimbang (balanced), dan reflektif (reflective). (S192)

The second question on the affordances and constraints of the PYP revealed more various responses. These issues of affordances and constraints were divided into three categories, i.e. those in the planning phase, in the teaching and learning processes, and those in the assessment phase. What follow are summaries of the respondents' responses concerning the strengths and weaknesses of each of the phases mentioned previously.

In relation to the planning phase, the respondents stated that one of the affordances of the PYP laid on its focus on its six transdisciplinary themes. It also had guidance on how to design a Program of Inquiry (PoI) for one year. It also came with a PYP planner which was very useful in creating a Unit of Inquiry (UoI). This UoI could last for several weeks and so there was no need to create a lesson plan every time the teacher came to class. Another strength, as the respondents expressed, laid on the requirement of collaborative planning on the part of the teachers to ensure the smoothness of UoI implementation in real classroom contexts. Below are the excerpts indicating the points.

Perencanaan materi dalam PYP sudah tersusun secara jelas dan diimplementasikan dengan tema-tema ... (S202) 
Planner dibuat dalam setahun sehingga guru tidak perlu membuat RPP setiap hari. (S135)

... Dalam merencanakan kegiatan pembelajaran, guru kelas berkoordinasi dengan guru kesenian dan guru penjaskes sehingga kegiatan pembelajaran menjadi terarah dan menjadi satu kesatuan yang utuh. (S241)

Apart from its affordances, the respondents also noted some constraints. The most common statement found out through the documented responses was that planning in the PYP was harder than that in the national curriculum because it had to be detailed for every UoI. As a consequence, the planning phase would require more time than that of the national curriculum. The followings are the extracts illustrating the point.

...Penyusunan rencana pembelajaran pada kurikulum PYP cukup rumit (dalam penyusunan membutuhkan pengetahuan dan keterampilan dalam penyusunan PoI yang harus mencantumkan 8 konsep secara merata) dibanding penyusunan rencana pembelajaran pada kurikulum Indonesia. (S192)

Penyusunan rencana pembelajaran membutuhkan waktu lama. (S002)

Interestingly, while the respondents suggested that collaborative planning was one of the strengths of the PYP planning phase, it was also considered as one of its biggest constraints as shown by the excerpts below.

... harus melibatkan banyak guru yang terdiri dari semua kelas untuk membuat pembelajaran yang berbeda-beda, namun tetap berkesinambungan. (S012)

Dalam membuat planner dibutuhkan kolaborasi dengan banyak guru, sedangkan kurikulum nasional guru mampu membuat planner tanpa bantuan kolaborasi. (S183)

Concerning its teaching and learning processes, the respondents noted that student-centeredness was one of the PYP affordances. Besides, as it lived on the spirit of inquiry, they reported that the PYP could enhance students' problem solving skills. This, as they suggested further, would encourage students to be reflective learners who were responsible for their own learning. Another affordance proposed by the respondents was the fact that the PYP could be made contextual to the students' circumstances, be it in their local state or in more global contexts. Accordingly, there were abundance of resources that could be used in the teaching and learning processes. The following are the quotations indicating these points.

Pembelajaran berpusat pada siswa. Keterampilan analisa, membuat laporan, dan berpikir kreatif lebih dilatih. (S081)

Siswa terlibat dalam penyelidikan dan pengembangan pembelajaran sehingga mereka memperoleh kesadaran dan pemahaman diri akan proses belajar yang mereka lalui, karena siswa di sini sebagai subjek pembelajaran (student-centred). (S159) 
... PYP memberikan provokasi agar siswa ingin tahu kemudian memberi waktu kepada siswa untuk melakukan refleksi dan konsolidasi. (S264)

... mendorong siswa untuk mengembangkan kemandirian dan mengambil tanggung jawab atas pembelajaran mereka sendiri sehingga siswa akan lebih aktif. (S124)

... bertumpu pada pengembangan kemampuan belajar siswa lewat pembelajaran secara inkuiri, siswa belajar dari konsep, ide, dan isu yang memiliki signifikansi lokal dan global sehingga dapat mengembangkan pemahaman di berbagai disiplin ilmu ... (S196)

... PYP menggunakan semua yang ada di kelas (baik guru maupun teman) dan di luar kelas (keluarga dan lingkungan) sebagai sumbersumber belajar. Jadi sumber belajar bukan terbatas pada buku saja. (S270)

Despite affordances in the teaching and learning processes of the PYP, the respondents reported some notable constraints as well. One of them was the difficulty that local teachers might have to deal when they had to implement the PYP in a class with a large number of students. Unavailability of textbooks aswell as affordable media and resources within the local frameworks made it more difficult for any local school wishing to adopt the curriculum. This was made even more difficult by the fact that, as the respondents underlined, the PYP requiredany internationally accepted language to be its medium of instruction. This was a quite noteworthy constraint because local teachers might not have enough proficiency in any of these languages. The excerpts below help clarifying the points.

... untuk dapat memfasilitasi siswa tidak mudah, oleh karena itu jumlah siswa pada setiap kelas harus dibatasi supaya guru mampu melihat bagaimana perkembangan setiap siswa. ... Media pembelajaran dan lingkungan belajarpun harus lebih diperhatikan ... (S012)

Panduan seperti buku ataupun fasilitas pendukung lainnya sulit didapat. Guru di Indonesia masih banyak yang kesulitan karena silabus, RPP dan materinya menggunakan bahasa Inggris. (S211)

The assessment phase of the PYP, as the respondents reported, comprised some affordances as well. The use of student portfolios in the process and product assessments as well as the use of such portfolios in the formative and summative assessment processes were among those affordances. Some ways of reporting the results of student assessment, such as the three kinds of conferences (i.e. teacherstudent conference, teacher-parent(s) conference, and student-led conference) held in the PYP and also the exhibition served as demonstrations of what the students had learned throughout their learning journey in the PYP were also considered as affordances of the PYP assessment stage. Below are the excerpts suggesting the ideas. 
... kurikulum ini menggunakan teknik penilaian portofolio anak dan dapat ditambahkan juga dengan observasi kinerja anak. Jadi, dalam kurikulum ini yang dinilai adalah bagaimana siswa tersebut berproses dari hari ke hari setiap hari ... bukan hanya sekedar hasil akhirnya saja yang menjadi penilaian bagi guru. (S012)

Penilaian dilakukan melalui penilaian formatif dan sumatif, selain itu siswa melakukan pameran di akhir program. Pelaporan dilakukan melalui beberapa cara yaitu student-led conference, teacher-parent conference, teacher-student conference, three-way conference dan written report. (S135)

The assessment phase of the PYP, however, was not without constraints, as the respondents suggested. The two major limitations noted were the difficulties in developing rubrics for assessing the student performances and the amount of time and energy that teachers needed to allocate in observing or assessing their students. The following quotations will help clarify the points.

Kendala guru yaitu membuat rubrik penilaian, karena yang dinilai mencakup beberapa ranah yaitu ranah kognitif, afektif, dan psikomotorik. (S091)

Memerlukan pengamatan menyeluruh dalam penilaian, sehingga guru memerlukan waktu dan tenaga ekstra. (S004)

The third query about whether it was relevant or not for a school to adopt and implement the PYP derived two varied responses. The majority of the respondents (around 80 per cent) believed that it was appropriate to adopt and implement the framework because of its fun and innovative learning and teaching processes. Besides, they agreed that the inquiry practices in the curriculum would help students to develop their creativity, their critical thinking skills and their foreign language proficiency. They could also help shape their characters as well as help them to learn to appreciate differences among them. Further, they noted that the PYP would help students understand things better than simply knowing facts. They also suggested that the curriculum was applicable in the local contexts because of its resemblances to the 2013 Curriculum that the government had decided to put into practice earlier this year. Some extracts illustrating the points are presented below.

Cara pengajaran yang lebih bervariasi, kreatif, dan inovatif membuat siswa senang dalam belajar, memudahkan siswa mencerna hal yang mereka pelajari ... (S046)

... dalam kurikulum PYP, siswa akan mendapatkan banyak pengetahuan yang lebih luas tetapi mandiri dan selalu mengajak siswa untuk berpikir kritis dan kreatif. (S185)

... siswa tersebut menguasai bahasa Inggris dan IT yang baik tanpa meninggalkan unsur kearifan lokal ... (S068)

Dalam kurikulum PYP juga ada sikap-sikap yang hendak dicapai oleh siswa seperti toleransi, kreativitas, kerja sama, kepercayaan diri, empati, komitmen, kepedulian, dll., sehingga sangat baik jika 
dipelajari oleh siswa untuk mengembangkan karakter pribadinya. (S047)

... siswa juga dilatih secara inkuiri (menemukan pemahaman sendiri) sehingga dapat peduli dengan lingkungan dan menghargai perbedaan. (S196)

...kurikulum ini mengajarkan anak ... untuk memahami dan bukan sekedar mengetahui ... (S091)

... PYP (Primary Years Program) menggunakan kurikulum tematik (transdisciplinary theme) di mana frameworknya diadaptasi untuk penyusunan Kurikulum 2013 ... (S175)

The 20 percent of respondents not supporting the adoption of the PYP pointed out two major things that might be the defects during its implementation. The first concerned with the professional abilities of the local teachers in putting the curriculum into practice as well as their familiarity with the curriculum itself. The second concerned with the facilities needed to support the implementation of the curriculum. These points are indicated by the quotations below.

... bahasa Inggris tidak diajarkan di semua sekolah, sehingga bila PYP diajarkan di Indonesia pelaksanaan tidak maksimal karena bahasa terbatas, guru sebagai fasilitator mungkin juga tidak banyak menguasai ... (S283)

... guru masih belum dapat sepenuhnya menjalankan thematic integrative, maka akan sulit bagi guru apabila menerapkan PYP dalam konteks pendidikan dasar di Indonesia. (S112)

Dalam proses pembelajaran pun tidak sembarangan dapat dilakukan karena dari segi fasilitas pembelajaran diperlukan alat yang canggih dan modern. Guru yang mengajarkan pun harus melakukan training terlebih dahulu agar dapat mengajar sesuai program dan ketentuan dariIBO. (S202)

The fourth question on what things or conditions that might support the adoption of the PYP in the local contexts bore somewhat common responses from the respondents. They believed that one supportive condition for the adoption was some similarities between the PYP and the 2013 Curriculum. Just as the local curriculum, as the respondents noted further, the PYP also shed lights to contextual teaching and learning processes as well as to inquiry learning that focused on students as the centre of those processes. Besides, the respondents believedthat the good value of PYP that taught children how to learn to appreciatedifferences could be another thing that might support the adoption and implementation of the curriculum. The quotations depicting the points are presented as follows.

... apabila Indonesia menggunakan kurikulum PYP tidak harus memulainya dari nol dan sudah ada panduaannya. Kurikulum di Indonesia (K 13) dengan PYP mempunyai pandangan yang sama bahwa dalam penilaian mengutamakan dari proses sampai produk. (S243) 
Wilayah Indonesia yang kaya dapat digunakan sebagai media pembelajaran kontekstual yang baik, (S115)

... PYP mirip dengan kurikulum 2013 karena menyuguhkan inkuiri di dalamnya. (S202)

... pembelajaran yang bersifat holistik, berpusat pada siswa dan dibangun dari kebutuhan siswa. (S031)

... keanekaragaman Indonesia yang dapat dikaitkan dengan berbagai pelajaran dan kemudian dapat menumbuhkan sikap yang baik dari diri siswa. (S013)

While there were supportive conditions, the respondents also proposed some noticeable defects that might interfere with the efforts to adopt the PYP in the local contexts. The first concerned with the unfamiliarity that teachers and parentsmight experience with the framework. Another limitation was related to the proficiencies of the teachers, especially their proficiency in foreign languages - English, in this case. The unavailability of any definite textbooks might cause another problem for the teachers. Last but not least, the respondents presumed that the fully adoption of the PYP framework in the local contexts would be costly because any school wishing to adopt the framework needed to have a legal licencefrom the IBO itself. Below are the excerpts indicating the points.

... biaya lisensi (ijin mengadopsi kurikulum) yang cukup mahal sehingga berpengaruh pada tarif biaya di sekolah yang menggunakan kurikulum tersebut. Selain itu juga masih perlu banyaknya sosialisasi yang dilakukan mengenai kurikulum tersebut kepada masyarakat karena belum banyak orang yang mengetahui tentang kurikulum tersebut. (S003)

... kuikulum IB tidak ada buku panduan untuk setiap pembelajaran ... (S054)

... kurangnya tenaga pendidik yang mampu berbahasa Inggris dengan baik. (S242)

The question about what kind of knowledge and skills required from a PYP teacher posed somewhat common responses from the respondents as well. They believed that being a PYP teacher, someone should have knowledge about the curriculum as well as about planning lessons in the curriculum. A would-be PYP teacher, as the respondents further suggested, should also be proficient in English, have adequate teaching skills as well as decent life skills. The prospective teacher should be already familiar with things like inquiry learning, developing rubrics or using technology in education. He/she should also be able to perform critical and creative thinking skills as well as social skills, such as being responsible, being able to communicate and cooperate with others, and being able to perform selfmanagement skills. The quotations below help illustrating the ideas.

... pengetahuan yang dibutuhkan guru yang menerapkan PYP adalah pengetahuan dan pemahaman awal mengenai kurikulum PYP ... kemudian bagaimana cara pembuatan perencanaan pembelajaran 
dalam kurikukum PYP itu sendiri, lalu kreativitas dan inovasi ...(S185) ... c. Pengetahuan mengenai pendekatan pembelajaran inkuiri karena PYP menggunakan pendekatan inkuiri; d. Keterampilan berbahasa Inggris karena bahasa pengantar pembelajaran dalam kurikulum PYP adalah bahasa Inggris; e. Keterampilan dalam teknologi karena dalam pembelajaran PYP, teknologi merupakan salah satu sarana pokok dalam mendukung kegiatan belajar mengajar ... (S192)

... keterampilan untuk memberi teladan life skills yang tertib, teratur, bertanggung-jawab, dll. ... (S072)

Selain itu guru harus dapat ... membuat rubrik penilaian, mampu berkolaborasi dengan guru-guru yang bersangkutan dan mampu mengemas pembelajaran agar lebih menarik. (S018)

Guru harus memiliki ... keterampilan berpikir, keterampilan sosial, keterampilan memanajemen diri sendiri dan ... keterampilan dalam berkomunikasi. (S112)

Seorang guru PYP juga harus seorang pemikir kritis ... (S004)

The last part of the survey concerned with what the respondents thought about what would be their advantages as well as limitations if they wished to be a PYP teacher. Responses to the question revealed more or less similar conditions of the student respondents themselves. They said that attending the PYP course offered to them during the semester. Along with their experiences in teaching elementary students they gained during their study had become their pluses. In addition, they also mentioned that their skills and knowledge in educational technology and their passion in teaching children could also be considered as theiradvantages if they were requested to teach using the PYP framework. Below are the quotations depicting their views.

... memperoleh pengetahuan dan informasi tentang PYP di bangku

kuliah; pengalaman mengajar di SD ... (S046)

... memiliki kemampuan dalam menggunakan teknologi dan

mengolah informasi ... (S192)

Pendukung lainnya adalah kecintaan saya terhadap anak-anak dan

kecintaan saya dalam mengajar. (S135)

Aside from the advantages they proposed, the respondents mentioned that their biggest limitation lied on their proficiency in English. They also stated that the limited meetings of the PYP course which were only once a week were not enough to give them thorough and complete understanding of the framework. Further, having no experience in teaching within the PYP framework yet was also proposed as their constraint concerning the curriculum. The respondents further suggested that they needed to improve their English proficiency and increase theirknowledge and skills in the PYP if they were requested to teach using the curriculum. The limitations and their wishes of improvement are shown in the excerpts below. 
... belum mempelajari keseluruhan PYP karena saya mendapatkan hanya 1 semester saja dan menurut saya itu kurang karena banyak pengetahuan yang belum saya pahami dan saya mengerti dan menjadi guru PYP itu tidaklah gampang dan harus menggunakan bahasa Inggris yang benar. (S124)

... saya belum mengetahui secara langsung gambaran mengenai kegiatan pembelajaran secara langsung di dalam kelas dengan menggunakan kurikulum PYP. (S280)

Yang harus saya tingkatkan adalah saya harus mau dan harus mempelajari lebih dalam kurikulum tersebut supaya saya mempunyai pengetahuan yang luas ... dan harus belajar bahasa Inggris yang baik dan benar. (S124)

The last question of the survey asking about what the student respondents had learned and gained so far from the PYP course they had attended revealed somewhat similar responses. They pointed out that during the one semester period of attending the course, they had learned about the similarities as well as differences between the PYP framework and the 2013 Curriculum implemented in the local schools. They also claimed that they had some insights on the possibility to combine both frameworks and implement the combination in the local contexts.Further, the respondents mentioned that they had learned how to plan lessons using the PYP framework. Their responses are shown in the following quotations.

Saya dapat belajar membuat unit of inquiry dan planners. Saya juga dapat mengetahui kelebihan dan kekurangan PYP dibanding dengan kurikulum yang ada di Indonesia ... saya dapat "mengawinkan" PYP dengan kurikulum nasional apabila diperlukan untuk menambah variasi dalam mengajar. (S015)

... saya sudah belajar mengenai pengajaran mata pelajaran pada PYP, cara membuat RPP yang digunakan dalam kurikulum PYP, juga belajar tentang hal-hal yang membedakan kurikulum PYP dengankurikulum di Indonesia. (S109)

... ternyata Kurikulum 2013 ini mengimplementasi dari kurikulum PYP, yakni proses pembelajarannya menggunakan tema-tema dan mengaitkan ke setiap mata pelajarannya dan setiap tema-tema tersebut memiliki nilai-nilai yang akan diterapkan dalam kehidupan sehari- hari. (S088)

The data gathered from the survey showed that, generally, the student respondents had positive attitudes toward the PYP. They believed that the PYP would help foster students' development. This meant that the curriculum would assist students to improve their inquiry skills and so develop their creativity as well as enhance their senses of independence and responsibility. This was the case because within the inquiry approach, students had to conduct inquiry and research and, hence, show their independence in learning (IBO, 2007:4). The respondents also indicated that this curriculum would also help students to develop their ability 
to identify and assume responsibility so that, as found in one of its key concepts (IBO, 2007:20), they were finally able to take socially responsible actions.

Next, the respondents viewed that the PYP could also help facilitate their students to be bilingual or even trilingual speakers because the framework, parallel to what was detailed in its Guidelines for developing a school language policy (IBO, 2008), required the use of at least one of the internationally accepted languages as its medium of instruction. Further, the PYP was viewed as having positive reception because of its commitment to create lifelong and internationallyminded learners. Through the inquiry approach, the PYP would help learners to actively enjoy learning and would make any effort to make this love of learning to sustain throughout their lives (IBO, 2007:4). The PYP would also help students who grew up in a rapidly changing world to be internationally minded learners who were always aware of the pace of change surrounding them, both locally and globally (IBO, 2007:19).

Further, this curriculum gained positive appraisals because it had clear and detailed planning, which was considered important on the teachers' part. The teachers had guidelines not only on what concepts, knowledge, skills, and attitudes that should be covered during the teaching and learning processes but also on how to create a Program of Inquiry (PoI) and a detailed Unit of Inquiry (UoI) generated from the PoI. Last but not least, the respondents viewed that the fact that the PYP assessed students' performances as well as their products as another positive value of the framework. This way, students' progress will be ableto be noted, recorded and given feedback wherever necessary (IBO, 2007).

These positive attitudes further lead to their support toward the possibility of implementing the PYP in their local contexts. They argued that one of the supporting factors' in implementing the curriculum was the resemblance that the local 2013 Curriculum bore with the PYP. Both curricula, as they indicated, were based on inquiry approach and, hence, were student-centred. In addition to the fact, the respondents also noted that the cultural diversity of the country could provide abundance resources for the learning and teaching processes and so help the students to develop their intercultural understanding and respect for individuals and their values and tradition (IBO, 2007:103).

However, the respondents also proposed some things which needed considerations when a school decided to adopt and implement the curriculum. The first thing needed to be thought over was the knowledge and skills of the teachers concerning the PYP. As the respondents suggested, PYP teachers were required to be familiar with implementing inquiry approach in class, including planning and assessing students within this inquiry framework. In order to be able to do this, these teachers needed skills, such as developing assessment tools and integrating technology in their teaching. PYP teachers also had to be creative and have adequate proficiency in any internationally accepted language (IBO, 2008).

Next, any school wishing to formally implement the PYP should also consider purchasing the license from the IBO which was quite costly. There was also problem concerning the unavailability of a detailed list of resource books used in the PYP. This was quite troublesome for most local teachers as they were 
used to be provided with certain resource books when they had to teach certain subjects to certain classes.

Looking at themselves, though, the student respondents believed that they might have possessed qualities which might of great assistance to them when they were required to be a PYP teacher later in the future. They proposed that their experience in teaching elementary students, the information and knowledge of the PYP they had got so far, as well as their ability to use technology in class would facilitate themselves when they had to teach using the PYP framework. Apart from these supporting qualities, however, they still wished to deepen their knowledge and improve their skills on the PYP. As they considered the PYP a good curriculum, they hoped they could learn more about it. They would like to learn more about how to create the PoI and UoI so that they could, in any possible manner, combine the PYP with any curriculum implemented by their schools later.

\section{Conclusion}

The primary school pre-service teachers had positive perspectives toward Primary Years Program (PYP) as well as toward its implementation in Indonesian primary schools. The pre-service teachers believed that, bearing similarities with the 2013 Curriculum, the PYP would be able to assist students in being lifelong learners by developing their inquiry skills and proficiencies in language other than their mother tongue. They also acknowledged that, learning within the framework, would help the students to be more creative, independent, and responsible. All things considered, the pre-service teachers approved that the PYP would be helpful to create socially responsible as well as international-minded individuals who were ready to keep up with the fast changing world surrounding them.

The majority of the pre-service teachers also had positive perceptions toward the possibility of any Indonesian primary school striving to adopt and implement the PYP for the reason that it would give great encouragement to Indonesian primary school students to be lifelong learners who were active and understanding toward differences existing among people from different background and cultures. They, however, posed some notes concerning PYPimplementation in any primary school within the Indonesian context. The first concerned with the professional abilities of the local teachers in putting the PYP into practice as well as their understanding of the framework itself. The second concerned with the facilities needed to support the implementation of the PYP which, they thought, could create problems for a number of schools in some areas. These, however, could be minimized by giving more thorough training on how to implement the PYP to the teachers so that, in any way, these teachers became familiar with the framework and, hence, were able to find ways to combine it with the 2013 Curriculum to minimize any constraint caused from the lack of facilities and resources in their areas.

Looking back at the results of this study, it is safe to imply that there is an urgency to develop programs aiming at enhancing the primary pre-service teachers' proficiency in any international language (e.g. English). Moreover, the Primary School Teacher Education Study Program of Sanata Dharma University 
should consider the possibility to offer more courses on the PYP so that the preservice teachers could learn more about the curriculum. They should also be given opportunities to practice teaching using the framework. This way, they would have experience implementing it in real classroom contexts.

\section{References}

Babin, C. \& Binns, C. (2011). International Baccalaureate Primary Years Programme Supplementary Workbook for Category 1: Making the PYP Happen.

Erickson, H. L. (2008). Stirring the head, heart, and soul: Redefining curriculum, instruction, and concept-based learning. Thousand Oaks, CA: Corwin Press.

International Baccalaureate Organization. (2007). Making the PYP happen: A curriculum framework for international primary education. Wiltshire: Antony Rowe Ltd.

. (2007). The IB primary years programme. Wiltshire: Antony Rowe Ltd. . (2008). Guidelines for developing a school language policy. Wiltshire: Antony Rowe Ltd.

. (2012). The IB primary years programme: Education for a better world. Wiltshire: Antony Rowe Ltd.

Jansen, H. (2010). The logic of qualitative survey research and its position in the field of social research methods. Forum Qualitative Sozialforschung/ Forum Qualitative Social Research, 11(2), Art. 11, http://nbnresolving.de/urn:nbn:de:0114-fqs1002110. 